\title{
J. Buchanan Young, M.B., C.M., D.Sc.
}

IT is with much regret that we record the death, on 17th March last, of Dr J. Buchanan Young, M.B., C.M., D.Sc.

Having graduated in Medicine at Edinburgh University in 1890, Dr Young took his D.Sc. in Public Health three years later. Meanwhile he had already joined the Forensic Medicine Department, which at that time was combined with Public Health, as an assistant-his services in practical chemistry becoming increasingly valuable as experience of teaching and analysis enabled him to fulfil the brilliant promise of his student days.

When Public Health was made a separate department in the University of Edinburgh in 1898, and Professor Hunter Stewart occupied the Chair then created, Dr Young became the first assistant in this new department, and entered with keen interest upon researches regarding the gaseous and bacterial impurities of air. While, however, he made valuable scientific contributions to existing knowledge of practical means of ventilation, it is chiefly by his geniality and conspicuous ability as a teacher of public health chemistry that he will be gratefully remembered by the numerous students whom he instructed since the Usher Institute was completed in 1902 and fully equipped for that purpose.

In $1921 \mathrm{Dr}$ Young was appointed as the first lecturer in the Public Health Department at Edinburgh, which appointment he continued to fill with his habitual geniality, ability, and devotion to duty until his death three years prior to his attaining the age limit of retirement.

He contributed to the 'ransactions of the Royal Society of' Edinburgh a paper on "Chemical and Bacteriological Examination of Soil," which attracted considerable attention at the time of its publication.

He was elected a Fellow of the Society in $1896 . \quad$ P. S. L. 